\title{
PENGETAHUAN PERAWAT TERHADAP K3RS
}

\author{
Elsya Fitri Syofian \\ elsyafitrisyofian93@gmail.com
}

\begin{abstract}
ABSTRAK
Perawat merupakan tenaga kesehatan yang sering berkontak langsung dengan pasien. Penting bagi perawat dalam meningkatkan pengetahuan tentang $\mathrm{K} 3$ demi menjaga keselamatan pasien dan dirinya sendiri agar terhindar dari bahaya dan kecelakaan saat bekerja. Kejadian kecelakaan kerja sering terjadi pada tenaga kesehatan khususnya perawat rumah sakit. Oleh karena itu, diperlukan upaya pembinaan pelaksanaan Keselamatan dan Kesehatan Kerja di Rumah Sakit (K3RS) agar terhidar dari kecelakaan kerja. Pengetahuan perawat merupakan salah satu faktor dalam keberhasilan penerapan K3RS. Pengetahuan perawat yang baik akan berdampak baik pula yaitu dapat meminimalisir risiko kecelakaan kerja. Sebaliknya, jika pengetahuan perawat kurang mengenai K3RS akan berdampak buruk yang beresiko terjadinya kecelakaan kerja.
\end{abstract}

Kata kunci: K3RS, Pengetahuan Perawat, Kecelakaan Kerja.

\section{Latar Belakang}

Kecelakaan kerja adalah kejadian yang tidak terduga dan tidak diharapkan. Kejadian kecelakaan kerja sering terjadi pada tenaga kesehatan khususnya perawat rumah sakit. Oleh karena itu, diperlukan upaya pembinaan pelaksanaan Keselamatan dan Kesehatan Kerja di Rumah Sakit (K3RS) agar terhidar dari kecelakaan kerja.
Kecelakaan kerja menjadi salah satu masalah urgen di lingkungan rumah sakit. Hal ini diakibatkan karena rumah sakit merupakan suatu unit pelayanan kesehatan yang memberikan pelayanan pada semua bidang dan jenis penyakit. Oleh sebab itu rumah sakit dituntut untuk dapat menyediakan dan menerapkan suatu upaya agar semua sumber daya manusia yang ada di rumah sakit dapat terlindungi, baik dari 
penyakit maupun kecelakaan akibat kerja (Ivana, Widjasena \& Jayanti, 2014).

Rumah sakit merupakan sarana pelayanan yang bergerak dibidang pelayanan jasa kesehatan yang mempunyai beragam persoalan tenaga kerja yang rumit dengan berbagai risiko terkena penyakit akibat kerja bahkan kecelakaan akibat kerja sesuai jenis pekerjaannya sehingga berkewajiban menerapkan upaya pembinaan Keselamatan dan Kesehatan Kerja Rumah Sakit (K3RS). Upaya ini dijalankan agar terhidar dari adanya risiko kecelakaan kerja (Astono, 2010).

Penerapan K3 di Indonesia diatur oleh Undang Undang Republik Indonesia Nomor 13 Tahun 2003 tentang Ketenagakerjaan, sedangkan K3 rumah sakit (K3RS) diatur oleh KEPMENKES RI Nomor 1087/MENKES/SK/VIII/2010. K3 pada umumnya bertujuan melindungi keselamatan dan kesehatan pekerja ataupun buruh dalam mewujudkan produktivitas kerja yang optimal. Tujuan diterapkannya K3RS adalah terciptanya cara kerja, lingkungan kerja yang sehat, aman, nyaman, dan dalam rangka meningkatkan derajat kesehatan karyawan RS. Pengetahuan K3RS yang baik diharapkan mampu menekan angka kecelakaan kerja karena individu tersebut dapat menerapakan tindakan yang sesuai dengan pengetahuan K3 yang dimilikinya.

Dalam hal ini, perawat merupakan tenaga kesehatan yang sering berkontak langsung dengan pasien. Penting bagi perawat dalam meningkatkan pengetahuan tentang $\mathrm{K} 3$ demi menjaga keselamatan pasien dan dirinya sendiri. Dengan tingkat pengetahuan perawat yang baik mengenai K3, maka akan meminimalisir kecelakaan saat bekerja yang dapat merugikan dirinya sendiri maupun pasien.

\section{Metode}

Metode yang digunakan adalah metode literature review. Metode yang berlandaskan teori yang mengumpulkan data yang telah disimpulkan dari berbagai sumber yaitu dari buku, koran, majalah, jurnal print maupun jurnal online, serta $e$ book dengan tahun paling tua 2012 yang memuat segala informasi mengenai pengetahuan perawat tentang Keselamatan dan Keselamatan Kerja di Rumah Sakit (K3RS). Dengan berdasarkan sumbersumber tersebut Saya dapat memahami bagaimana pengetahuan berpengaruh terhadap kemanan bekerja agar meminimalisir resiko terjadinya kecelakaan dalam pekerjaan. 


\section{Hasil}

Pengetahuan merupakan salah satu faktor dalam penerapan Kesehatan dan Keselamatan Kerja di Rumah Sakit khususnya bagi tenaga kesehatan yang sering berinteraksi langsung dengan pasien yaitu perawat. Pengetahuan perawat terhadap Kesehatan dan Keselamatan Kerja di Rumah Sakit (K3RS) yang baik akan mempengaruhi tingkat kemanan saat bekerja. Sebaliknya jika pengetahuan perawat yang masih kurang akan berdampak buruk bagi dirinya maupun pasien yang akan mengakibatkan resiko kecelakaan kerja. Beberapa faktor yang mempengaruhi tingkat pengetahuan perawat dalam melaksanakan K3 yaitu pendidikan, usia, dan lama kerja (pengalaman).

Selain itu perilaku perawat yang negative dapat menimbulkan masalah dalam kecelakaan kerja. Insiden kecelakaan kerja yang sering terjadi pada perawat ialah tertusuk jarum suntik hingga terpapar cairan pasien. Ini menandakan pengetahuan perawat masih kurang dalam melaksanakan K3RS. Perawat yang masih menyepelekan penggunaan APD dan tidak melaksanakan prosedur sesuai SOP akan lebih beresiko mengalami kecelakaan kerja di rumah sakit. Perawat perlu bersikap positif saat akan menerapkan perilaku yang aman saat bekerja.

Sikap perawat yang proaktif dalam mencari informasi-informasi mengenai K3 akan menambah pengetahuan perawat dalam meningkatkan pemahaman mengenai resiko kecelakaan dalam kerja yang dikarenakan kurang patuhnya dan ketidaktahuan perawat tentang bahaya serta cara untuk mencegah meskipun telah mengetahui adanya resiko. Ini yang akan melandasi bagaimana sikap perawat saat akan mencegah resiko tersebut agar menjadi aman saat bekerja.

Perlu adanya upaya yang dilakukan oleh pihak rumah sakit demi menciptakan perilaku aman pada komponen tenaga kesehatan, dengan membuat SOP, penyediaan APD, pengadaan pelatihanpelatihan $\mathrm{K} 3$, sosialisasi mengenai kebijakan-kebijakan baru maupun informasi-informasi baru yang berhubungan dengan jobdesc perawat. Sosialisasi tersebut dapat dilakukan melalui media sosialisasi oleh bagian komite K3RS yang berisi tentang prosedur K3 terutama untuk pencegahan kejadian kecelakaan kerja. Pihak rumah sakit khususnya komite K3RS dapat melakukan pengawasan terhadap perilaku dan kinerja perawat secara rutin. Akan tetapi tidak semua perawat dapat 
menerapkan perilaku aman pada saat bekerja. Dengan menciptakan safety culture dalam lingkungan kerja diharapkan dapat menjadikan seluruh perawat menerapkan perilaku aman baik dalam bekerja maupun dalam kegiatan sehari-hari untuk mengurangi resiko kecelakaan saat bekerja.

\section{Pembahasan}

Pelayanan kesehatan di rumah sakit memiliki beberapa komponen, perawat adalah salah satu tenaga pelayanan kesehatan yang berinteraksi dengan pasien yang intensitasnya paling tinggi dibandingkan komponen lainnya. Perawat sebagai anggota inti tenaga kesehatan yang jumlahnya terbesar di rumah sakit (40-60\%) dan dimana pelayanan keperawatan yang diberikan merupakan bagian integral dari pelayanan kesehatan memiliki peran kunci dalam mewujudkan keselamatan dan kesehatan kerja (K3) di Rumah Sakit (Depkes, 2007).

Dalam hal ini perawat akan cenderung terkena kecelakaan saat bekerja di rumah sakit. Kecelakaan kerja pada tenaga medis khususnya perawat yang paling sering terjadi yaitu tertusuk jarum suntik hingga terpapar oleh cairan pasien. Perawat pelaksana yang memiliki pengetahuan serta perilaku yang baik dalam penerapan manajemen Kesehatan dan Keselamatan Kerja (K3) akan cenderung meminimalisir resiko kecelakaan kerja.

Salah satu faktor utama dalam meminimalisir resiko kecelakaan kerja di rumah sakit yaitu pengetahuan perawat. Ada hubungan antara pengetahuan umum K3 pada tenaga keperawatan dengan kejadian kecelakaan kerja. Jika pengetahuan umum K3 baik maka kejadian kecelakaan kerja akan menurun. Apabila terjadi peningkatan pengetahuan K3 dari perawat maka akan menurunkan kecelakaan kerja. Semakin rendah pengetahuan seseorang maka akan semakin tinggi risiko terjadi kecelakaan kerja, sebaliknya semakin tinggi pengetahuan seseorang maka akan semakin rendah risiko terjadinya kecelakaan kerja. Perawat yang memiliki pengetahuan yang baik akan mampu membedakan dan memahami potensi bahaya di tempat kerjanya serta dapat melakukan pekerjaan sesuai dengan prosedur sehingga kecelakaan kerja bisa dihindari atau dicegah. Dengan begitu, akan menurunkan tingkat resiko kecelakaan yang terjadi pada perawat maupun pasien.

Faktor yang dapat memengaruhi tingkat pengetahuan $\mathrm{K} 3$ pada perawat adalah 
1. Pendidikan

Pendidikan yang tinggi dapat meningkatkan pengetahuan seseorang. Oleh sebab itu, semakin tinggi pendidikan seseorang, pengetahuan yang dimilikinya akan semakin baik.

2. Usia

Usia dapat mempengaruhi tingkat kematangan seseorang dalam berpikir dan menangkap suatu hal yang pada akhirnya dapat meningkatkan pengetahuan seseorang.

3. Lama kerja

Pengetahuan yang cukup juga dipengaruhi oleh lama kerja seseorang. Pengetahuan dapat diperoleh melalui pengalaman, baik pengalaman sendiri ataupun pengalaman orang lain. Sumber pengetahuan K3 tidak hanya seseorang dapatkan dari institusi saja tetapi bisa juga didapatkan sebelum seseorang tersebut memasuki institusi tersebut.

Selain itu persepsi perawat juga dapat berpengaruh dalam melaksanakan K3RS. Persepsi merupakan suatu proses pencarian informasi yang dilakukan oleh perawat sebelum melakukan suatu tindakan.
Persepsi perawat tentang K3 menunjukkan bagaimana perawat mampu mencari tahu tentang pentingnya K3 baik melalui brosur, leaflet, SOP yang disediakan di ruangan maupun media informasi lainnya. Perawat juga dituntut untuk faham bagaimana cara pencegahan kecelakaan serta penanganan yang dapat dilakukan apabila kecelakaan terjadi. Pemahaman tersebut akan menimbulkan persepsi yang baik dalam diri perawat tentang K3 sehingga hal ini akan meningkatkan perilakunya dalam menjaga keselamatan.

Selain persepsi, sikap juga mempengaruhi perilaku perawat ditinjau dari segi faktor internal (Notoadmodjo, 2010). Seorang perawat dalam melaksanakan manajemen K3 harus memiliki sikap yang sesuai dengan nilainilai kesehatan dimana seluruh nilai positif yang ada dalam dirinya menjadi pendorong perilaku sehat dan menjadi upaya dalam meningkatkan kesehatan dan keselamatan selama bekerja. Berbagai cara yang dapat dilakukan untuk meningkatkan persepsi, pengetahuan dan sikap perawat dalam menjaga kesehatan dan keselamatan selama bekerja, diantaranya dengan memberikan promosi kesehatan dan pelatihan tentang K3 sehingga hal ini diharapkan mampu 
merubah perilaku perawat menjadi lebih baik.

Disamping tingkat kemampuan perawat terhadap K3RS, komponen lain untuk meminimalisir kecelakaan kerja adalah sikap dan pelatihan. Perawat yang memiliki sikap negative terhadap pencegahan cidera benda tajam hampir dua kali cenderung terkena cidera benda tajam dibandingkan dengan yang bersikap positif. Faktor yang menyebabkan perawat berperilaku tidak aman yaitu sikap negative perawat yang tidak disiplin dalam menggunakan Alat Pelindung Diri (APD) dan Standar Operasional Prosedur (SOP) yang berlaku di RS belum sesuai dengan standar Depkes RI tahun 2006. Rumah sakit dapat mengurangi jumlah kejadian tertusuk benda tajam dengan meningkatkan sikap perawat dimana sikap sangat berhubungan dengan perilaku. Perawat perlu bersikap positif terhadap prosedur pelaksanaan keselamatan dan kesehatan kerja dalam bentuk mendukung/menyetujui segala program K3 khususnya untuk pencegahan kecelakaan kerja maka diusahakan adanya sikap yang pro aktif untuk mengaplikasikan ilmu baru tentang pelaksanaan keselamatan dan kesehatan kerja. Semakin pro aktif mengaplikasikan ilmu baru maka akan semakin bersikap positif tentang pelaksanaan K3 sehingga akan mengurangi kejadian kecelakaan kerja.

Kebutuhan pelatihan keselamatan dan kesehatan kerja di Rumah Sakit satu dengan Rumah Sakit lain berbeda sesuai sifat bahaya, skala kegiatan dan kondisi petugas kesehatan (Ramli, 2010). Pelatihan keselamatan dan kesehatan kerja sangat penting mengingat kebanyakan kecelakaan terjadi pada pekerja yang belum terbiasa bekerja secara selamat. Penyebabnya adalah ketidaktahuan tentang bahaya atau cara mencegahnya meskipun tahu tentang adanya suatu resiko. Perawat diharapkan untuk mengikuti pelatihan dan mengaplikasikan ilmu yang didapat dalam melaksanakan tugas yang mengacu pada prosedur K3 terutama untuk pencegahan kejadian kecelakaan kerja. Perlu peran Komite K3RS untuk menyelenggarakan pelatihan internal bagi seluruh perawat di Rumah Sakit untuk mengadakan pelatihan K3 yang lengkap dan secara berkala bagi seluruh perawat agar memiliki pengetahuan dan keterampilan dalam pelaksanaan tugas sesuai prosedur.

Profesi keperawatan sebaiknya terus mengembangkan pengetahuan dan keterampilan di bidang manajemen keperawatan khususnya terkait Kesehatan dan Keselamatan Kerja (K3) sehingga 
pelayanan yang diberikan dapat lebih optimal dan berkualitas tanpa melupakan tingkat kesehatan dan keselamatan bagi pemberi asuhan keperawatan. Rumah sakit sebaiknya selalu dapat memberikan dukungan dan memfasilitasi para perawat untuk dapat meningkatkan pengetahuan dengan pelatihan serta melatih keterampilannya sehingga dapat bekerja dengan lebih aman.

\section{Penutup}

Pengetahuan perawat yang baik akan berpengaruh pada penerapapan K3RS yang baik pula. Tetapi walau sudah baik perlu di lakukan penyuluhan tentang pengetahuan K3 pada perawat yang masih terdapat perawat yang memiliki pengetahuan kurang baik agar bisa menambah wawasan dan meningkatkan pengetahuan tentang K3 serta perlu dilakukan pelatihan K3. Disarankan kepada pihak manajemen rumah sakit bersama dengan Komite (organisasi) K3 rumah sakit agar meningkatkan pengetahuan perawat mengenai K3 melalui sosialisasi, pelatihan $\mathrm{K} 3$, rapat internal ruangan perawatan berkala sebelum bekerja yang diharapkan timbul peningkatan sikap positif perawat tentang $\mathrm{K} 3$, timbul kesadaran pribadi dan menjadi budaya K3. Meningkatkan kesadaran perawat dengan memenuhi standar prosedur yang telah dibuat dan menggunakan alat pelindung diri yang sesuai sehingga kecelakaan kerja bisa dicegah.

Dengan melakukan pelatihan maka perawat akan terlatih dalam mencegah resiko-resiko kecelakaan kerja. Perlu adanya pemantauan pada tenaga kesehatan dalam menjalankan K3RS agar dapat dipastikan bekerja dengan aman. Pihak rumah sakit juga dapat mencukupi dengan fasilitasfasilitas untuk meningkatkan pemahaman perawat dalam K3RS. 


\section{Daftar Pustaka}

Alayyannur, P. A. (2018). Korelasi Komitmen Manajemen dan Pelatihan K3 dengan Pengetahuan di Rumah Sakit "X". Journal of Industrial Hygiene and Occupational Health, 2(2), 102-111.

Ardi, S. Z., \& Hariyono, W. (2018). Analisa Penerapan Budaya Perilaku Keselamatan dan Kesehatan Kerja di Rumah Sakit. Jurnal Kesmas Fakutas Kesehatan Masyarakat, 12(1), 15-20.

Hanifa, N. D., Respati, T., \& Susanti, Y. (2017). Hubungan Pengetahuan dengan Upaya Penerapan K3 pada Perawat. Bandung Meeting on Global Medicine \& Health (BaMGMH), 1(1), 144-149.

Hasbullah, H., Wahyu, A., \& Awaluddin, A. (2020). Pengaruh Pelatihan Fire Safety Management Terhadap Motivasi K3 Perawat RSUP Dr. Wahidin Sudirohusodo. Hasanuddin Journal of Public Health, 1(1), 83-91.

Ivana, A., Widjasena, B., \& Jayanti, S. (2014). Analisa Komitmen Manajemen Rumah Sakit (RS) terhadap Keselamatan dan Kesehatan Kerja (K3) pada RS Prima Medika Pemalang. Jurnal Kesehatan Masyarakat (e-Journal), 2(1), 35-41.
Kumayas, P. E., Kawatu, P. A., \& Warouw, F. (2019). Hubungan Pengetahuan dan Sikap Dengan Penerapan Kesehatan dan Keselamatan Kerja (K3) Pada Perawat di Rumah Sakit Bhayangkara TK III Manado. KESMAS, 8(7), 366-371.

Nazirah, R., \& Yuswardi, Y. (2017). Perilaku Perawat dalam Penerapan Manajemen Kesehatan dan Keselamatan Kerja (K3) di Aceh. Idea nursing journal, 8(3).

Putri, S., Santoso, S., \& Rahayu, E. P. (2018). Pelaksanaan keselamatan dan kesehatan kerja terhadap Kejadian Kecelakaan Kerja Perawat Rumah Sakit. Jurnal Endurance, 3(2), 271-277.

Ramdan, I. M., \& Rahman, A. (2018). Analisis Risiko Kesehatan dan Keselamatan Kerja (K3) pada Perawat. Jurnal Keperawatan Padjadjaran, 5(3), 229-241.

Rifai, M. (2017). Hubungan Pengetahuan dan Partisipasi Keselamatan dan Kesehatan Kerja (K3) Pada Perawat dengan Kejadian Kecelakaan Kerja di Rumah Sakit X Yogyakarta. Jurnal Publikasi Kesehatan Masyarakat Indonesia, 4(3), 3. 
Simamora, R. H. (2011). Role Conflict of Nurse Relationship With Performance in The Emergency Unit of Hospitals RSD DR. Soebandi Jember. The Malaysian Journal of Nursing (MJN), 3(2), 23-32. 